\title{
Den barske og den blide
}

\section{Anna Libak}

\section{Har Putin og Medvedev forskellige strategier over for Nordkaukasus? Det spørgsmål blev rejst, da Moskva i slutningen af marts blev ramt af selv- mordsterror i metroen}

Kremlologien har ændret sig. I sovjettiden bestod den i at følge med i, hvem der stod tættest på generalsekretæren under parader på den Røde Plads. I dag består den frem for alt i studier af de meningsforskelle, som analytikerne mener at kunne udlede af præsident Dmitrij Medvedevs og ministerpræsident Vladimir Putins udtalelser.

Sådan var det også, da to kvindelige selvmordsterrorister den 29. marts i morgenmyldretiden sprængte sig selv i luften på metrostationerne Park Kultury og Lubjanka i Moskva. 40 mennesker omkom og 160 blev såret.

I de vestlige medier blev tragedien genstand for større opmærksomhed end andre terrorangreb i Rusland de senere år. Af flere grunde. For det første fordi det skete midt den russiske hovedstad. For det andet fordi det fandt sted ved lokaliteter, som de fleste vesterlændinge ken- der: Lubjanka er navnet på hovedkvarteret for Den Føderale Sikkerhedstjeneste - det gamle KGB nu FSB - som ligger tæt på metrostationen, og Park Kultury ligger klos op af Gorkijparken, som de fleste vestlige turister i Moskva har besøgt.

$\mathrm{Og}$ for det tredje fordi tragedien var en oplagt anledning til at gøre status over Medvedevs præsidentperiode. Han havde været præsident i næsten halvdelen af sin periode, og det var - opgjort efter tabstal - det værste terrorangreb uden for Nordkaukasus i hans præsidenttid.

Medvedev blev valgt i marts 2008, og selv om der siden har været flere store terroraktioner (som for eksempel imod Nevskij Ekspressen fra Moskva til Skt. Petersborg, der kostede 27 livet), skal man tilbage til 2004 for at finde et terrorangreb af samme dimensioner i landets hovedstad. Dengang eksploderede en bombe i metroen mellem Avtosa- 
vodskaja og Paveletskaja og dræbte omkring 50 mennesker og sårede hen ved 150 .

Myndighederne tøvede i marts ikke med at udpege terrorister fra Nordkaukasus som gerningsmænd. Billederne fra overvågningskameraerne viste to sortklædte kvinder, der fuldstændig lignede 'sorte enker', som de kvindelige selvmordsterrorister bliver kaldt. Sådanne 'sorte enker' har stået bag adskillige terrorangreb, siden den anden tjetjenske krig blev indledt i 1999, og de er blevet døbt sådan, fordi der erfaringsmæssigt ofte er tale om kvinder, der hævner sig for tabet af deres mænd og sønner i krigen.

\section{Fra Dagestan, ikke Tjetjenien}

Ifølge myndighederne er det bekræftet, at der også i marts i år var tale om kvindelige terrorister fra Nordkaukasus. Kvinden, der sprængte sig selv i luften, da toget holdt på Park Kultury metrostationen, var angiveligt den 18-årige Jannet Abdulajeva fra Tjetjeniens naborepublik Dagestan. Kvinden, der sprængte sig luften ved Park Kultury var angiveligt den 28-årige Mariam Sjaripova, der ligeledes kom fra Dagestan, og som var gift med den berygtede bandeleder Magomedal Vagabov. Ifølge FSB's chef Aleksandr Bortnikov har myndighederne desuden fundet frem til bagmændene og deres håndlangere $o g$ har foretaget tilbageholdelser og afhøringer af nogle af dem. I skrivende stund har FSB dog ikke sat navne på dem.

At terroristerne kom fra Dagestan, og ikke fra Tjetjenien selv, var en yderligere grund til at beskæftige sig med tragedien. For hvad ville præsident Medvedev egentlig stille op med den kendsgerning, at oprørsbevægelserne i dag har udvidet deres operationsradius til hele det nordkaukasiske territorium, som er blevet afgørende destabiliseret efter den anden tjetjenske krig? Ville han, ligesom sin ministerpræsident og herre Vladimir Putin, reagere gammeltestamentligt og kræve øje for øje, tand for tand? Eller for nu at citere Putin korrekt, så lovede han denne gang at hive terroristerne "op af kloakken og ud i dagslyset”. Dermed byggede han videre på sit tidligere berømte løfte om at "skylle terroristerne ud i lokummet" og viste sig altså som en ordholdende mand: For har man - som lovet skyllet terrorister ud i lokummet, ja så må man jo i sagens natur hive dem op af kloakken, hvis man vil have fat i dem igen.

\section{Rodet reaktion}

I den vestlige presse, særlig den anglikanske, hvor man ynder at portrættere Putin og Medvedev som Ruslands svar på Doktor Jekyll og Mr. Hyde, spejdede man ivrigt efter forskelle mellem de tos reaktioner. Og fandt dem til sidst. Medvedevs indledningsvist noget 
rodede og selvmodsigende optræden gjorde det ikke helt nemt.

Hans første udtalelser var lange og akademiske og handlede om at styrke antiterrorberedskabet og om at udbygge myndighedernes institutionelle muligheder for tværgående antiterrorbekæmpelsesforanstaltninger. Og senere, om aftenen, da han lagde blomster på perronen på Lubjankas metrostation, forsøgte han sig med en barskere og mere hårdtslående jargon - muligvis inspireret af Putins kloakmetaforik. Medvedev kaldte nu terroristerne for 'dyr' og slog fast, at deres handlinger var 'hinsides enhver moral', uanset hvilke motiver de havde handlet ud fra.

Et par dage senere dukkede præsidenten imidlertid overraskende op i Makhatjkala, hovedstaden i Dagestan, der i dagene efter terrorangrebet i Moskva selv blev udsat for en række terroraktioner, hvoraf et kostede 12 mennesker livet. Selv om Medvedev her fremkom med adskillige skarpe og uforsonlige udfald mod terroristerne, som ikke lod Putin noget efter, fokuserede vestlig presse på, at han også fandt tid til at understrege, at de sociale problemer i Nordkaukasus i sig selv var med til at stimulere terrorisme.

Det fremgik også af den fempunktsplan, som han fremlagde i Makhatjkala som svar på terroren: Ud over hårdere antiterroroperationer og en skærpelse af straffen for medløberi (om den så bestod i at 'lave suppe' eller 'vaske tøj' for terroristerne), krævede han iværksættelse af velfærdsprogrammer, der skulle styrke befolkningen socialt, økonomisk, uddannelsesmæssigt og åndeligt. Endvidere skulle der på ny gøres forsøg på at få folk til at forlade oprørsbevægelsen frivilligt ved at tilbyde dem frit lejde. Programmet blev overordnet udlagt som bekræftelse på, at hans strategi for Nordkaukasus er væesentligt anderledes end ministerpræsidentens.

I den britiske avis The Times hed det: "Selvmordsbomberne i Moskva har bragt ny tragedie til Rusland, men de har også vist præsident Medvedev i et helt nyt lys. Han har domineret scenen som Ruslands leder i den sidste uge, meget mere end ministerpræsident Putin, og han har vist politisk tæft og mod i sine svar på begivenhederne. Han har kombineret hård retorik om kampen mod terrorismen med praktiske forslag til, hvordan man kan forbedre tilværelsen for folk i det uroplagede Nordkaukasus, idet han gentagne gange har mindet alle om, at de er borgere i Rusland."

Hvor The Times lagde vægt på, at Medvedev nu trådte i karakter og formulerede en ny Nordkaukasuspolitik, havde New York Times en lidt anderledes vinkling. Her fokuserede man på, at Medvedev allerede havde lagt en ny politik, som risikerede at blive ødelagt af selvmordsbomberne, hvis Putin brugte dem som anledning til at gennemtvinge yder- 
ligere stramninger: "Mandagens bomber kom på et usikkert tidspunkt for Ruslands Kaukasus-politik, som har vaklet mellem den muskelsvulmende knockoutpolitik, som Putin foretrak som præsident, og den forsigtige liberalisering, som er blevet introduceret efter at Mr. Medvedev overtog magten."

Som vidnesbyrd om Medvedevs liberalitet anførte begge aviser, at Medvedev overraskende i januar besluttede at oprette et nyt føderalt distrikt for Nordkaukasus (så Rusland nu er opdelt i otte distrikter), og gøre guvernøren i Krasnojarsk Aleksandr Khloponin sin befuldmægtigede udsending - og samtidig lade ham indtræde som viceministerpræsident i regeringen.

Udnævnelsen blev mødt med begejstring af de politiske analytikere - herunder flere Kreml-kritiske - i Moskva. Både fordi Khloponin er kendt som en dygtig og ukorrumperet erhvervsmand og guvernør, og fordi han i modsætning til flere af de syv andre udsendinge ikke har en fortid i sikkerhedstjenesterne. Det syntes at vidne om, at med-ondt-skalondt-fordrives-strategien var afløst af et større fokus på befolkningens sociale problemer og på de regionale og lokale myndigheders korruption og ansvarsløshed.

\section{Stramninger forude}

En af dem der frygtede, at selvmordsbomberne ville blive brugt som anledning til yderligere stramninger, var politologen Lilja Sjevtsova fra Moskvas Carnegie Center. "Vores system er ikke demokratisk. Statens og myndighedernes sikkerhed går forud for de almindelige borgeres. Vi kan derfor forvente, at der vil blive draget en politisk konsekvens, og at det kan resultere i en yderligere begrænsning af borgernes politiske og civile rettigheder", sagde hun til Radio Free Europe.

Og det ser ud til, at hun får ret. Nogle uger efter terrorbomberne fremsatte regeringen i Dumaen et lovforslag, som skal give de ansatte i sikkerhedstjenesten FBS mulighed for at fremsætte en officiel advarsel over for borgere, hvis handlinger vurderes at gøde jorden for ekstremisme. Hvis man ikke retter sig efter advarslen, kan man imødese en bøde.

Allerede i dag har FSB mulighed for at fremsætte den slags advarsler over for myndigheder, virksomheder og organisationer og kræve, at "de årsager og betingelser, som fremmer fremvæksten af trusler mod Ruslands sikkerhed elimineres." Men hidtil har man ikke haft mulighed for at gøre det over for konkrete borgere.

Det er ikke svært at se, at en sådan lov vil gøre det muligt at indskrænke borgernes frihedsrettigheder væsentligt. Netop fordi det er helt op til FSB's fortolkning, hvad der kan 'gøde jorden for terror' - som altså 
ikke er opstået endnu - er det i princippet kun fantasien, der sætter grænser for, hvad der kan udløse en officiel advarsel. Man kan sagtens argumentere for, at et kritisk læserbrev vendt mod regeringen kan gøde jorden for ekstremisme, for så vidt som det svækker tilliden til landets myndigheder.

Kritikerne har også hæftet sig ved, at lovforslaget kommer fra regeringen, selv om det drejer sig om at styrke beføjelserne for sikkerhedstjenesten, der ellers hører under præsidenten. Kan det så tages som et udtryk for, at Medvedevs blødere linje over for Nordkaukasus nu er lagt i graven? Tja, det ville til en begyndelse forudsætte, der virkelig var tale om to modsatrettede politiske strategier for Nordkaukasus.

\section{To aspekter af samme politik}

Men måske er sandheden snarere, at der er tale om to aspekter af den samme politik, hvor Putin og Medvedev inkarnerer hver sin. Kreml og Det Hvide Hus ønsker at bruge en blanding af stok og gulerod i kampen mod terror - fuldstændig som man ser det $i$ andre lande. Eller sagt ligeud: Det sandsynlige er, at Medvedevs mere liberale tilgang er afstemt med Putin på forhånd, og at Medvedev kun er så liberal, som Putin tillader.

Det er i hvert fald opfattelsens blandt flertallet af russerne I flere meningsmålinger har et flertal ladet forstå, at de ikke tror på en modsætning mellem de to, men opfatter det som noget, journalisterne har fundet på.

I en helt ny meningsmåling fra det uafhængige analyseinstitut Levada tilkendegav hele 70 procent af de adspurgte, at de er tilfredse med Dmitrij Medvedevs indsats som præsident. Men i samme meningsmåling sagde 66 procent, at de er overbevist om, at han er under Vladimir Putins kontrol. Direktøren for Levada, Lev Gudkov, udtalte, at Medvedev "ikke fremstår som en uafhængig politiker på trods af alle sine udtalelser om behovet for modernisering, retsstat, kamp mod korruptionen osv. Folk kan godt lide at høre disse ting, men de kan dårligt tro på dem. De forventninger, som Medvedev har vakt hos de liberalt sindede dele af samfundet, er stadig kun forventninger."

Det synspunkt indtager også Vladimir Pribylovskij, præsident for tænketanken Panorama, der siger til svpressa.ru, at man ikke skal betragte Medvedev som præsident, men snarere som en af viceministerpræsidenterne.

"I den magtstruktur, som er skabt af Putin, vil jeg tildele Medvedev rollen som den yngste i triumviratet Putin-Setjin-Medvedev," siger Pribylovskij med henvisning til den tidligere vicechef for præsidentadministrationen Igor Setjin, som Putin tog med sig til det Hvide Hus (hvor regeringen holder til) og gjorde til 
viceministerpræsident. Setjin er desuden bestyrelsesformand i det statslige olieselskab Rosneft, der overtog en stor luns af den detroniserede oligark Mikhail Khodorkovskijs olieselskab Yukos.

Pribylovskij ser det dog som sandsynligt, at det var Medvedevs eget påfund at udnævne Khloponin og gøre ham til chef for et nyt føderalt distrikt i Nordkaukasus. Pribylovskij siger, at det må Medvedev have lobbyet igennem over for Putin, eftersom det helt sikkert ikke er noget, som førsteviceministerpræsident Setjin går ind for, da det nye distrikts territorier er taget fra Det Sydlige Føderale Distrikt, hvor faderen til Setjins svigersøn Vladimir Ustinov er befuldmægtiget.

"Det kan godt være, at det var Medvedev som tog initiativ til at udnævne chefen for det nye nordkaukausiske distrikt, Aleksandr Khloponin", siger Pribylovskij. "Det vil jeg tro. Jeg kan ikke forestille mig, at Igor Setjin har rådet Putin til at tage halvdelen af distriktet fra sin svigersøns far. Og hvis det absolut skulle gøres, så tror jeg, at Setjin ville foreslå en anden end Khloponin. Men det har længe været under overvejelse at oprette et Nordkaukasisk Distrikt, så det kunne sagtens være sket under Putin også."

\section{Nummer tre i hierakiet}

Om Medvedevs rolle i triumviratet, siger Pribylovskij i øvrigt:
"Han er blevet nr. tre i magtens hierarki i de to år, hvor han har været præsident. Hans ansvarsområde er som viceministerpræsident for juridiske spørgsmål. Det område har han fået som en slags aflad, og Medvedev har anbragt sine folk netop dér. Desuden fungerer Medvedev som rådgiver for Putin ved udnævnelser af guvernører. Formelt er det Medvedev, der foreslår regionsledere over for den føderale forsamling (Dumaen og Føderationsrådet. Red.), men reelt er det igen sådan, at Putin lytter til hans råd, og på baggrund af dem udnævner han guvernørerne. Jeg vil antage, at det var Medvedevs initiativ at udnævne Nikita Belykh til guvernør for Kirov Oblast. Men hans råd er ikke udslagsgivende.

Præsidenten ville for eksempel gerne udnævne en medstuderende til Khanty-Mansijskij Distriktet, men Gennadij Timtjenko (oliemand og nær ven af Putin, red.) pressede på for at få sin kandidat Natalja Komarova igennem. (Det blev hende. Red.) Det viser Medvedevs reelle tyngde i beslutningsprocessen."

I samme artikel siger Nikolaj Petrov fra Carnegie i Moskva, at set fra magthavernes synspunkt er Medvedevs rolle primært at forbedre forholdet til udlandet:

"Han er loyal over for Putin, det er bevist gennem års arbejde, og socialt går han godt i spænd med de russiske og de vestlige liberale. Han forbedrer landets image ved at ud- 
sende positive signaler. $\mathrm{Og}$ hans hovedbeskæftigelse er netop at sende disse signaler.

Det er svært for os at vurdere, om han er en succes, for en del af vores borgere og eksperter forholder sig temmelig skeptisk til hans udtalelser, fordi de ikke følges op af konkret handling. Men i Vesten bliver de om ikke slugt råt, så i hvert fald taget seriøst.

Medvedev forsøger at gøre sig gældende dér, hvor der ikke er hårde begrænsninger. I arbejdsdelingen mellem ham og Putin, har Medvedev en vis frihed i den retsjuridiske sfære. Her pågår der reformer, men deres resultat er modstridende. Man kan ikke tale om en styrkelse af den dømmende magt, som Medvedev gør."

\section{Scenarier i Nordkaukasus}

Tror man på disse eksperter, har der altså aldrig været kamp mellem $\mathrm{Pu}$ tin og Medvedev om at formulere en Nordkaukasus-politik.

Men selv hvis man accepterer, at Medvedev står for en radikalt anderledes og blødere politik i Nordkaukasus, så vil han have yderst svært ved at gennemføre den.

For det første er der modstanden i befolkningen: Nye meningsmålinger - efter selvmordsterroren - tyder på, at hvis russerne blev bedt om at vælge mellem en barsk og en kompromissøgende linje over for de nordkaukasiske terrorister, så ville de vælge den barske linje. I alle meningsmålinger er der flere adspurgte, som foretrækker en hård frem for en blid linje, og andelen af adspurgte, der vil sætte hårdt mod hårdt, er i øvrigt vokset de senere år.

For det andet er der den faktiske situation i området, som er præget af vilkårlighed, vold, korruption og magtfuldkommenhed.

Medvedevs udnævnelser har ikke formået at ændre situationen til det bedre. I efteråret 2008 afsatte Medvedev den tidligere så forhadte ingusjetiske præsident Murat Sjasikov (i Tjetjeniens naborepublik mod vest, Ingusjetien) og erstattede ham med den regionalt langt mere populære Junus-Bek Jevkurov, og i januar i år udnævnte han som nævnt Aleksandr Khloponin. Men retssikkerheden i Nordkaukasus er ikke væsentligt styrket i den periode.

Det er nok at give ét eksempel. I begyndelsen af marts - altså efter de to udnævnelser - kom sagen om mordet på journalisten og juristen Magomed Jevlojev for retten i Ingusjetien igen.

Magomed Jevlojev var berømt i hele Ingusjetien for sin hjemmeside Ingushetiya.ru (siden omdøbt til http:/ /ingushetiyaru.org), hvor han afslørede myndighedernes magtmisbrug.

Allermest berømt blev han for aktionen 'jeg stemte ikke' efter det russiske parlamentsvalg i 2007.

Officielt havde 98 procent af ingusjeterne stemt, og 99 procent af dem 
havde stemt på Putins parti Forenet Rusland. De stemmetal var så fantasifulde, at Jevlojev organiserede en underskriftsindsamling blandt ingusjetere, der ikke havde stemt. I løbet af få måneder havde han samlet 90.000 underskrifter, der svarede til over halvdelen af vælgerbefolkningen i Ingusjetien. (Den var på 165.768, ifølge Reuters. Red.) De mange tons underskrifter blev siden afleveret på lastbiler til statsadvokaten i Moskva, hvor der blev lagt låg på sagen.

Den 31. august 2008 tog Jevlojev flyet fra Moskva til Ingusjetiens hovedstad Manas. Han havde ellers fordi han frygtede for sit liv - hovedsageligt opholdt sig udenlands i månederne op til sin død. Om bord på flyet viste sig også at være Ingusjetiens præsident Sjasikov. Det kom til et heftigt skænderi mellem de to, og Sjasikov gav sig til at ringe på mobilen. Jevlojev gættede, at han var i fare og orienterede på sms kolleger, der lovede at hente ham i lufthavnen. Men allerede ved foden af landingstrappen blev han arresteret og puffet ind i en bil. En kortege af biler - med ham i den ene - kørte nu bort; og nogle af hans venner og kolleger satte efter i egen bil. På et tidspunkt delte bilkortegen sig, og vennerne valgte den forkerte.

Jevlojev blev i mellemtiden skudt i bilen og smidt i en grøft. Politiofficeren, der senere blev dømt for uagtsomt - ja uagtsomt - manddrab, hævdede, at Jevlojev havde forsøgt at vriste pistolen fra ham. En ansat i Ingusjetiens indenrigsministerium har efterfølgende indrømmet, at han først underskrev arrestordren mod Jevlojev efter dennes død og blev truet til at holde kæft. Der er aldrig blevet fulgt op hans tilståelse.

Morderen - som var den ingusjetiske indenrigsministers bodyguard (og nevø) - blev umiddelbart efter anvist arbejde i Moskva. Han deltog ikke i retssagen og blev kun afhørt for lukkede døre.

Den myrdedes forældre ankede den påfaldende milde dom på to år - men det fik de ikke noget ud af. Tværtimod. I begyndelsen af marts kom den nemlig for retten, som sænkede straffen til to års hjemmearrest på grundlag af en ny bestemmelse, der giver mulighed for strafafsoning i hjemmet mod den dømtes accept af visse indskrænkninger i sin bevægelsesfrihed.

Løsladelsen har vakt bedrøvelse hos menneskerettighedsforkæmpere i hele Rusland. De håber om nogen på, at Medvedev har en anden politik for Nordkaukasus, og at den indbefatter retssikkerhed for borgerne.

Anna Libak er litteraturredaktør på Weekendavisen og medlem af forretningsudvalget i Det Udenrigspolitiske Selskab og Udenrigs' redaktionskomité. 